Аналізуючи графічні залежності рис. 1, можна зробити загальний висновок, що застосування режиму барботування сировини, що поділяється, дозволяє інтенсифікувати процес УФ-поділу БВМС [3] в порівнянні з УФ в тупиковому режимі в 1,5...1,6 рази при УФ-обробці сколотин, в 1,3..1,4 рази при УФ-обробці знежиреного молока, в 1,4...1,5 рази при УФ-обробці сироватки з-під кислого сиру.

\title{
Література:
}

1. Золотухіна I. В. Наукове обгрунтування технологій напівфабрикатів на основі цільового використання нутрієнтів білкововуглеводної молочної сировини : дис. ... д-ра техн. наук: 05.18.16. Харків, 2021. 400 с.

2. Дейниченко Г. В., Золотухина И. В. Исследование свойств ультрафильтрационных мембран // Современные технологии сельскохозяйственного производства: сборник научных статей по материалам XXIII Международной научно-практической конференции. Гродно: ГГАУ, 2020. С. 239-241.

3. Дейниченко Г. В., Золотухіна І. В., Кравченко Т. В. Визначення баричних режимів отримання ультрафільтраційних концентратів білково-вуглеводної молочної сировини // Сучасні напрямки технології та механізації процесів переробних і харчових виробництв: зб. наук. праць / Харк. нац. техн. ун-т с/г ім. П. Василенка. Харків: ХНТУСГ ім. П. Василенка, 2019. Вип. 207. С. 176-182.

DOI https://doi.org/10.30525/978-9934-26-172-5-19

\section{ДЖЕМ 3 ЖУРАВЛИНИ ЗБАГАЧЕНИЙ ПЕКТИНОМ ДЛЯ ВИВЕДЕННЯ ВАЖКИХ МЕТАЛІВ ТА РАДІОНУКЛІДІВ ЗІ ЗНИЖЕНИМ ГЛІКЕМІЧНИМ ІНДЕКСОМ}

\author{
Руденко Б. А. \\ студент \\ Дніпровський національний університет імені Олеся Гончара \\ м. Дніпро, Україна
}

В Україні існує проблема забруднення навколишнього середовища важкими металами і радіонуклідами, які становлять велику небезпеку для здоров'я людини. Тому стає питання що до виправлення або зменшення наслідків такого забруднення. На ринку завжди є попит на 
кондитерську продукцію, це стоється і джему. Це популярний продукт серед великою кількості груп населення. Джем це продукт багатий на пектини, але його збагачення додатковим пектином із бурякового жому підсилює ефект і робить його більш вираженим.

Пектини мають комплексоутворювальну здатність, це можливість утворювати нерозчинні сполуки з різноманітними металами, такими як стронцій, кобальт, свинець, кальцій та іншими важкими металами, які не перетравлюються і погано виводяться з організму організму.

Встановлено, що найбільшу комплексоутворювальна здатність мають низькоетерифіковані пектини, до яких відноситься пектин із бурякового жому. Використання таких пектинів у якості харчових добавок обмежене, тому що вони мають низьку желюючу здатність, але головою сировиною джему була обрана журавлина, яка має в своєму складі велику кількість пектинів з більш високою етерифікацією.

Аналіз комплексоутворювальної здатності пектинів різного походження показав, що буряковий пектин показу найкращі результати по сорбції, особливо іонів свинцю та цезію [1, с. 11, 2, с. 215.]. Для свинцю зв'язування інтенсивніше відбувається в кислому середовищі, виготовлений джем створює кисле середовище, а його $\mathrm{pH}$ дорівнює 3,5. I хоча комплексувальна здатність для цезію і стронцію краща в лужному середовище, за рахунок використання пектину із бурякового жому, який відразу показує хороші результати у зв'язуванні цих речовин, їх комплексування все ще ефективне.

Також було проведено часткова заміна цукру на фруктозу за для зниження глікемічного індексу. Найважливіша користь фруктози для здоров'я полягає в тому, що вона слабко впливає на рівень глюкози в крові, а отже, підходить для продуктів дієтичного та діабетичного харчування з низьким глікемічним індексом.

Перед внесенням пектину до бланшованої журавлини його попередньо змішали 3 цукром, фруктозою та водою у співвідношенні $5 \%, 10 \%, 15 \%$ до маси суміші. Найкращий результат показав продукт із додаванням 10\% додаткового пектину. Зі збільшенням пектинових речовин у складі джему зростає і його комплектувальна здатність та вологість. Вплив на смак кінцевого продукту не $є$ суттєвим, а консистенція відповідає вимогам.

Таким чином, враховуючи вище зазначене, можна зробити висновок про доцільність виготовлення джему і використання бурякового пектину для виведення важких металів і радіонуклідів. 


\section{Література:}

1. Купчик Л.А., Картель М.Т., Ніколайчук А.А. Вилучення іонів токсичних важких металів модифікованими пектиновмісними відходами харчової промисловості. Екологічний вісник. 2008. № 3. C. 11-12.

2. Глаголева Л.Э., Корнеева О.С., Г.П. Шуваева. Характеристика сорбционных свойств растительных некрохмальных полисахаридных комплексов. Химия растительного сырья. 2012. № 1. С. 215-216. 